Janusz Węgrzecki

Uniwersytet Kardynała Stefana Wyszyńskiego

\title{
Spór o wartości i jego implikacje dla konfliktu politycznego według Benedykta XVI
}

DOI: 10.19195/1643-0328.22.5

Słowa kluczowe: aksjologia, Benedykt XVI, konflikt, polityka, religia

\section{Wprowadzenie}

W artykule rekonstruuję współczesne podejście nauczania społecznego Kościoła w okresie pontyfikatu Benedykta XVI w kontekście poziomów konfliktu aksjologicznego w polityce. Najpierw udzielam odpowiedzi na pytanie stawiane przez Benedykta XVI: Jaka religia vel jaki Kościół jest potrzebny demokratycznemu państwu? Papież odpowiada, że demokracja potrzebuje religii vel Kościoła takiego, który sam nie generuje konfliktu politycznego oraz łagodzi istniejący konflikt przez właściwy dla Kościoła udział w sporze o wartości. W kolejnych krokach omawiam podejście Benedykta XVI do działań Kościoła w kontekście relacji między wartościami a polityką. Sprowadza się ona do czterech kroków: Kościół zorientowany na problemy społeczne, a nie polityczne; Kościół promotorem uniwersalnych wartości; skutki działań Kościoła nabierają znaczenia politycznego mimo ich niepolitycznej genezy; Kościół koryguje publiczny rozum obywatelski i polityczny w odniesieniu do uniwersalnych wartości. Kończę wnioskami z przeprowadzonej analizy.

\section{Jaka religia vel jaki Kościół potrzebny jest demokratycznemu państwu?}

Spór o wartości może dotyczyć kilku poziomów. Dla Benedykta XVI dwa z nich nabierają szczególnego znaczenia. Pierwszy dotyczy wartości fundamentalnych w ogóle, a w polityce w szczególności. Usytuowany na poziomie kulturowym, metapolitycznym, jest związany z pytaniami: Jaki powinien być związek wartości, takich jak prawda, dobro, piękno, wolność, sprawiedliwość, z polityką, z procesem politycznym? Jaka powinna być relacja między tymi wartościami a władzą polityczną, obywatelami, elitą polityczną? Jest 
to spór o preferowaną etykę polityczną. Drugi dotyczy wzajemnych relacji między religią i polityką. Wiąże się on z pytaniami: Jaką wartość posiada religia $\mathrm{w}$ odniesieniu do polityki: pozytywną, negatywną czy obojętną? Jaka ma być pożądana obecność religii, konkretnej denominacji w sferze publicznej? Jak ma wyglądać relacja państwo-Kościół - relacja uznana za pożądaną, czyli stanowiąca specyficzną wartość?

Inspiracji do rozpatrzenia tych problemów dostarcza dzieło Benedykta XVI, który $\mathrm{w}$ drugiej fazie swego pontyfikatu sformułował oryginalną doktrynę dotyczącą wartości, Kościoła, życia publicznego, życia politycznego, demokratycznego państwa prawa oraz relacji między nimi, co bez wątpienia stanowi oryginalny wkład papieża w rozwój nauczania społecznego Kościoła. Sformułował ją w ramach trzech przemówień wygłoszonych w trzech stolicach europejskich (Praga, Londyn, Berlin) podczas swych podróży apostolskich. Papież spotykał się z władzami politycznymi, administracyjnymi, korpusem dyplomatycznym, z różnymi grupami społecznymi, przedstawicielami parlamentu. Większość adresatów przemówień papieskich nie była katolikami i używa zsekularyzowanego rozumu, co nie jest równoznaczne $\mathrm{z}$ brakiem otwartości na dialog z przedstawicielami religii. Ogólna myśl papieża mówi, że Kościół nie powinien sam generować konfliktów aksjologicznych oraz powinien sprzyjać łagodzeniu zaistniałego aksjologicznego konfliktu politycznego.

Doktryna Benedykta XVI sprowadza się do czterech kroków, które można wyrazić w następujący sposób. Po pierwsze, Kościół powinien być skoncentrowany społecznie, a nie politycznie. Kościół nie powinien być ani fundamentalistyczny, ani zideologizowany. Po drugie, Kościół powinien być promotorem wartości. Po trzecie, niepolityczna w swojej genezie działalność Kościoła, skoncentrowana na promocji wartości, w swoich skutkach prowadzi do politycznych rozstrzygnięć. Władze polityczne stoją więc przed pytaniem: Czy, jak i w jakim zakresie chronić wartości? Po czwarte, Kościół wypełnia „korekcyjną” rolę wobec publicznego i politycznego rozumu, współcześnie często zsekularyzowanego. Korekcyjna rola polega na pomocy w odejściu od uznawania antywartości i przylgnięciu do wartości oraz na podtrzymaniu w trwaniu przy już wcześniej akceptowanych wartościach. Rola ta dotyczy społeczeństwa i władz publicznych. Papież Benedykt XVI niechętnie mówi w tym kontekście o samym Kościele. Wartości są ogólnoludzkie, uniwersalne, nie mają zatem charakteru kościelnego, wyznaniowego. W życiu politycznym szczególne znaczenie mają wartości, do jakich prowadzą uniwersalne normy moralne. Za tymi wartościami powinni się opowiadać wszyscy ludzie, a nie tylko członkowie Kościoła. Zadanie korygowania błędnego rozpoznania wartości spoczywa na wszystkich, nie tylko na Kościele. Podobnie - zadanie trwania przy wartościach. Papież jednak wyraźnie odróżnia możliwości zsekularyzowanego i religijnego rozumu. Korekcyjną rolę może pełnić rozum ożywiony wiarą. Benedykt XVI mówi konsekwentnie o „korekcyjnej” roli religii, a nie tylko Kościoła. Współczesną kwestią społeczną są uniwersalne wartości, w szczególności moralne, które dzisiaj są zagrożone. Kościół $\mathrm{w}$ dialogu z innymi kościołami i chrześcijańskimi wspólnotami kościelnymi, z innymi religiami oraz ludźmi dobrej woli powinien podejmować działania przeciwstawiające się degradacji wartości w życiu osobistym, publicznym i politycznym. 


\section{Kościół skoncentrowany społecznie, a nie politycznie}

Papież formułuje kategoryczne twierdzenia negatywne mówiące, jaki nie powinien być Kościół:

Nie dla Kościoła bezpośrednio zaangażowanego politycznie.

Nie dla aktywnego współtworzenia przez Kościół sprawiedliwego ładu politycznego. Jest to wyłączne zadanie państwa.

Nie dla Kościoła funkcji zastępczych, funkcji integrującej społeczeństwo i legitymizującej władzę oraz stabilizującej system społeczny i polityczny, czyli nie dla Kościoła pełniącego funkcję religii obywatelskiej w społeczeństwie ${ }^{1}$.

Pozytywne sformułowania Benedykta XVI mówią z kolei, że Kościół kieruje się zasadą „miłość w prawdzie” oraz zasadą „cały człowiek i wszyscy ludzie”. Należy to rozumieć w taki sposób, że Kościół sprzyja i zachęca do powszechnego, globalnego braterstwa ludzi i pokojowego współżycia oraz integralnego rozwoju ludzi, ludów, narodów i społeczeństw. Według Benedykta XVI powyższe dwie zasady są kryteriami wartościowych kultur i religii. Zdaniem papieża „religia nigdy nie może usprawiedliwiać nietolerancji lub wojen. Nie można zabijać w imię Boga. Wszystkie religie powinny nakłaniać do właściwego używania rozumu i propagować wartości etyczne, kształtujące współżycie społeczne"2. Zaangażowanie na rzecz rozwoju obejmuje także zaangażowanie społeczne Kościoła. Egzemplifikacją tego ostatniego będzie zaangażowanie Kościoła w przezwyciężanie nędzy ${ }^{3}$.

\section{Kościół promotorem wartości}

Benedykt XVI postrzega Kościół realizujący swoją misję w świecie jako „sól ziemi”. Jego misja polega na posłudze Słowa, sakramentów, miłości. Kościół powinien być mistyczny, powinien być sobą i powinien prowadzić aktywność ściśle religijną. W ramach tej misji Kościół odkrywa prawdę o człowieku i prawdę o wartościach.

Według papieża aksjologia jest ściśle związana $\mathrm{z}$ antropologią. Skoro istnieje obiektywna natura ludzka, to ściśle z nią skorelowane będą wartości stanowiące swoiste uzewnętrznienie tejże natury. Naturę ludzką poznajemy nie wprost, ale za pośrednictwem moralnego prawa naturalnego. Z kolei za wyraz prawa naturalnego można uznać uniwersalne wartości kulturowe i moralne. Jedną z dróg do uznania uniwersalnych wartości jest bogata spuścizna duchowych i kulturowych wartości stanowiących dziedzictwo Europy ${ }^{4}$. Takie współczesne ujęcie prawa naturalnego proponuje papież Benedykt XVI. Jakie są te odwieczne, a zatem również współczesne wartości? Papież wymienia prawdę, piękno i dobro. Dodaje zaraz wolność, ale ze względu na liczne związane z nią nie-

\footnotetext{
1 Zob. A. Dylus, Polityka w perspektywie etycznej i religijnej, Warszawa 2016, s. 431-433.

2 Benedykt XVI, Adhortacja Verbum Domini, nr 102.

3 Zob. Benedykt XVI, Adhortacja Sacramentum Caritatis, nr 90.

4 Dalsza część stanowi prezentację głównych wątków przemówienia papieskiego w Pradze.
} 
porozumienia mówi o prawdziwej wolności, wolności poszukującej celu, poszukującej prawdy, prawdziwego dobra. Według papieża „prawda jest zasadą przewodnią wolności, a dobro jest doskonałą formą wolności”. Pragnienie prawdy, piękna i dobra zbliża ludzi we wspólnym dążeniu do sprawiedliwości, wolności, pokoju i dobrobytu. Wartości te kształtują tożsamość narodów i są najgłębszą podstawą jedności w kwestiach etycznych ludów i narodów Europy. Papież doprecyzowuje znaczenie wolności w wymiarze publicznym i politycznym. Wolność jest przede wszystkim wartością osobową, „wolność odnajduje swe najgłębsze znaczenie jako ojczyzna duchowa". W wymiarze publicznym prowadzi do pełnego poszanowania „odrębności dziedziny polityki i sfery religii - co w rzeczywistości chroni prawo obywateli do wyrażania przekonań religijnych i życia zgodnie z nimi”. Papież doprecyzowuje znaczenie prawdy. Wierność prawdzie jest „jedyną gwarancją wolności i integralnego rozwoju człowieka”. Prawdy nie należy się lękać.

Poszukiwanie prawdy nie stanowi bynajmniej żadnego zagrożenia dla tolerancji czy pluralizmu kulturowego, a umożliwia osiągnięcie porozumienia, sprawia, że debata publiczna jest rzeczowa, uczciwa i odpowiedzialna, oraz gwarantuje jedność, której nie można uzyskać posługując się mglistymi pojęciami integracji.

Do wyrażenia uniwersalnego znaczenia piękna w każdej jego postaci służy papieżowi piękno Pragi: „Urzekające piękno jego [miasta - JW] kościołów, zamku, placów i mostów może zwrócić nasze umysły tylko ku Bogu”. Szczególną wartością podkreślaną przez papieża jest jedność dobra, prawdy i piękna — jedność, która umożliwia „znalezienie porozumienia co do wspólnych wartości". Papież wskazuje na jeszcze jedną wartość społeczną będącą pochodną wartości uniwersalnych ukształtowanych w twórczym spotkaniu tradycji klasycznej i Ewangelii, które „dało początek wizji człowieka i społeczeństwa uwzględniającej obecność Boga pośród nas". Jest to paradygmat etosu osobowego i społecznego: żyj tak, jakby Bóg istniał. Papież identyfikuje także przyczyny odrzucenia uniwersalnych wartości, ich jedności oraz negacji wartości od nich pochodnych. Uznaje za nie cynizm, „który przeczy wielkości naszego dążenia do prawdy”, oraz relatywizm, „niszczący te właśnie wartości, które są natchnieniem do budowania zjednoczonego, braterskiego świata" 5 .

Podstawowa lista wartości moralnych, które mają znaczenie w życiu społecznym, publicznym, prawnym i państwowym, została wyrażona w nocie Kongregacji Nauki Wiary kierowanej przez kardynała Ratzingera:

Gdy dochodzi do konfrontacji [polityki - JW] z zasadami moralnymi, które nie mogą być uchylone, nie dopuszczają wyjątków ani żadnych kompromisów, zadanie katolików staje się szczególnie ważne i odpowiedzialne. W obliczu tych fundamentalnych i niezbywalnych nakazów etycznych wierzący muszą zdawać sobie sprawę, że w grę wchodzi sama istota ładu moralnego, od którego zależy integralne dobro ludzkiej osoby. Odnosi się to na przykład do ustaw dotyczących aborcji i eutanazji [...]; ustawy te muszą mianowicie chronić podstawowe prawo do życia od chwili poczęcia aż po jego naturalny kres. W myśl tej samej zasady należy przypominać o obowiązku poszanowania i ochrony praw ludzkiego embrionu. Podobnie też, w obliczu współczesnego prawodawstwa dotyczącego rozwodów, trzeba zabiegać o ochronę i uświadamianie wartości rodziny — opartej na monogamicznym małżeństwie osób przeciwnej płci — której jedność i trwałość win-

${ }^{5}$ Zob. Benedykt XVI, Przemówienie do władz politycznych i administracyjnych Republiki Czeskiej oraz korpusu dyplomatycznego. 26 września 2009 - Praga, http://www.opoka.org.pl/biblioteka/W/WP/benedykt_xvi/przemówienia/czechy2009_władze_26092009.htlm (dostęp: 1 maja 2016). 
na być zabezpieczona; niedopuszczalne są jakiekolwiek próby prawnego zrównania z rodziną innych form współżycia ani też prawnego uznania owych form. Również zagwarantowanie rodzicom swobody w wychowaniu swoich dzieci jest niezbywalnym prawem, uznawanym zresztą przez międzynarodowe deklaracje praw człowieka. W tym samym duchu należy zadbać o ochronę społeczną nieletnich i o wyzwolenie tych, którzy ulegli współczesnym formom niewolnictwa (takim na przykład jak narkomania albo zmuszanie do prostytucji). Na tej liście nie może zabraknąć prawa do wolności religijnej ani troski o rozwój gospodarczy, służący człowiekowi i dobru wspólnemu, respektujący nakazy sprawiedliwości społecznej i ludzkiej solidarności oraz zasadę pomocniczości [...]. I wreszcie czyż można nie uwzględnić w tym wykazie wielkiej sprawy pokoju? ${ }^{6}$

O zadaniach Kościoła w promowaniu uniwersalnych wartości moralnych mówił Benedykt XVI i zawężoną listę tych wartości zawarł w Adhortacji Sacramentum Caritatis:

Kult oddawany Bogu w istocie nie jest nigdy aktem czysto prywatnym, bez wpływu na nasze społeczne więzi: wymaga on publicznego świadectwa naszej wiary. Dotyczy to oczywiście wszystkich ochrzczonych, ale szczególnie dotyczy tych, którzy z racji pozycji społecznej czy politycznej, jaką zajmują, muszą podejmować decyzje dotyczące wartości fundamentalnych, takich jak szacunek i obrona ludzkiego życia od poczęcia aż do naturalnej śmierci, jak rodzina oparta na małżeństwie mężczyzny i kobiety, wolność wychowania dzieci oraz promocja dobra wspólnego we wszystkich jego formach. Te wartości nie podlegają negocjacjom. Dlatego katoliccy politycy oraz ustawodawcy, świadomi swej poważnej odpowiedzialności społecznej, winni się czuć szczególnie przynaglani przez swe sumienie uformowane w prawy sposób, by przedstawiać oraz wspierać prawa inspirowane przez wartości oparte na ludzkiej naturze ${ }^{7}$.

Nasuwa się kilka uwag na temat wartości, które przedstawia Benedykt XVI. Są one uniwersalne, dostępne poznawczo każdemu normalnie funkcjonującemu rozumowi i sumieniu: rozumowi i sumieniu chrześcijańskiemu, wyznającemu religię monoteistyczną, niemonoteistyczną, agnostycznemu, ateistycznemu; rozumowi i sumieniu obywatela i władcy. Wartości zobowiązują do ich uznania i przestrzegania w życiu osobistym każdego człowieka, a także publicznym i państwowym, niezależnie od ustroju i epoki. W odniesieniu do demokratycznego państwa prawa moralne i wartości uniwersalne nie podlegają negocjacjom. Nie mogą być w jakiejkolwiek procedurze demokratycznej przegłosowane i uznane za nieobowiązujące. Nie są także efektem konsensusu. Zawsze obowiązują i stanowią podstawę jedności życia społecznego, publicznego i państwowego. Katolicy poznają wartości na dwóch drogach: rozumu i sumienia, tak jak wszyscy, oraz na drodze wiary i obecności w życiu Kościoła. Katolicy są zobowiązani do tego, aby być promotorami wartości. Katolicy świeccy, którzy są politykami, są ponadto zobowiązani do podejmowania wszelkich starań prowadzących do zagwarantowania wartościom uniwersalnym ochrony prawnej.

\section{Kościół niepolitycznie polityczny}

Benedyktowi XVI rozważającemu relacje między Kościołem a sferą polityczną bliskie jest stwierdzenie: „Wolny Kościół w wolnym państwie” (Charles Montalambert) czy wizja Kościoła umiarkowanie oddzielonego od państwa. Trzeba jednak odpowiedzieć

${ }^{6}$ Kongregacja Nauki Wiary, Nota doktrynalna o niektórych aspektach działalności i postępowania katolików w życiu politycznym, nr 1.

7 Benedykt XVI, Adhortacja Sacramentum Caritatis, nr 83. 
na pytanie: Jakie jest właściwe miejsce Kościoła w procesie politycznym? Papież Benedykt XVI bardzo precyzyjnie wyjaśnił, na czym polega niepolityczne działanie Kościoła, które prowadzi jednak do skutków natury politycznej. Mówiąc o zadaniu państwa, a zatem także demokratycznego państwa prawa, stwierdza, że

podstawową zasadą państwa powinno być usilne dążenie do sprawiedliwości i że celem sprawiedliwego porządku społecznego jest zagwarantowanie każdemu jego udziału w części dóbr wspólnych, z zachowaniem zasady pomocniczości ${ }^{8}$.

Konsekwentnie, centralnym zadaniem polityki jest sprawiedliwy porządek społeczeństwa i państwa. W tym świetle jasno widać, że bezpośrednią misją Kościoła nie może być zadanie o charakterze politycznym.

Kościół nie może i nie powinien podejmować walki politycznej, aby zrealizować jak najbardziej sprawiedliwe społeczeństwo. Nie może i nie powinien stawiać się na miejscu państwa. [...] Sprawiedliwa społeczność nie może być dziełem Kościoła, lecz powinna być realizowana przez politykę 9 .

Znaczenie niepolitycznej polityczności Kościoła trafnie rozjaśnia Piotr Mazurkiewicz, mówiąc, że chodzi o stwierdzenie, iż

nie tylko byty z natury polityczne, jak państwo czy partie polityczne, ale także inne instytucje, nie stawiające sobie za cel pierwszorzędny politycznego zaangażowania, mają wpływ na kształt życia politycznego. Pierwsze - w sposób bezpośredni, drugie - w sposób pośredni. Kościół [...] należy do drugiej grupy. Pytanie o niepolityczną polityczność Kościoła byłoby więc pytaniem o to, w jaki sposób Kościół instytucjonalny podejmuje swoją odpowiedzialność za kształt życia społecznego i politycznego, nie wchodząc w rolę instytucji politycznej. Jak zatem instytucja Kościoła powinna być obecna w polityce bez ryzyka utraty swej tożsamości? ${ }^{10}$

Newralgicznym problemem współczesnych demokracji, którego Kościół nie może pominąć, jest polityczny wymiar zasad, czyli wartości moralnych. Benedykt XVI stwierdza, że „ostatecznym kryterium i podstawą pracy [...] polityka nie powinien być sukces ani tym bardziej korzyść materialna”, lecz służba „prawu i walka z panowaniem niesprawiedliwości" ${ }^{\prime 1}$. Papież diagnozuje zagrożenia współczesnych demokracji w relacji: polityka a wartości moralne.

Pierwsze polega na przeświadczeniu i praktyce, że wszystko, a zatem także wartości moralne, podlega regułom procedury demokratycznej. Prowadzi to do uznania wartości moralnych poprzez proces arbitralnego ich uzgadniania w debacie publicznej i politycznej. W ten sposób zapomina się o tym, że wartości moralne są „podstawą procesu demokratycznego”, a jedyną gwarancją ich obowiązywania staje się „nietrwały konsensus społeczny".

Drugie zagrożenie polega na stosowaniu „pragmatycznych rozwiązań w odniesieniu do złożonych problemów społecznych i etycznych". Takie rozwiązanie prowadzi do nie-

${ }^{8}$ Benedykt XVI, Encyklika Deus Caritas est, nr 26.

9 Ibidem, nr 28.

10 P. Mazurkiewicz, Niepolityczna polityczność Kościoła, „Chrześcijaństwo - Świat - Polityka. Zeszyty Społecznej Myśli Kościoła” 2012, nr 13 (1), s. 5.

11 Zob. Benedykt XVI, Przemówienie w Bundestagu. 22 września 2011-Berlin, http://www.opoka.org. pl/biblioteka/W/WP/benedykt_xvi/przemowienia/niemcy2011_bundestag_22092011.htlm (dostęp: 1 maja 2016). 
rozpoznania i niedocenienia wartości,godności człowieka i ludzkości”"12. W praktyce polega ono na wyrzuceniu wartości ze sfery polityki. Papież identyfikuje przyczynę tego zagrożenia. Odpowiedzialny jest za nią światopogląd pozytywistyczny, pozytywistyczna koncepcja natury i rozumu.

Pozytywistyczna koncepcja natury - stwierdza papież — która pojmuje ją w sposób czysto funkcjonalny, tak jak postrzegają ją nauki przyrodnicze, nie może tworzyć żadnego mostu łączącego ją z etosem i prawem, lecz rodzi jedynie nowe odpowiedzi funkcjonalne.

Według pozytywistycznego rozumu poza zakres racjonalności należy wykluczyć wszystko to, co nie podlega weryfikacji lub falsyfikacji. Zdaniem papieża tam,

gdzie panuje wyłącznie rozum pozytywistyczny — a tak dzieje się w znacznym stopniu w naszej świadomości publicznej - nie dopuszcza się do głosu klasycznych źródeł wiedzy o etosie i prawie ${ }^{13}$.

Demokratyczny proces stanowienia prawa powinien pozostawać w stałej relacji do uniwersalnych wartości moralnych. A to wymaga porzucenia w tej kwestii rozumu pozytywistycznego.

Sformułowanie „niepolitycznie polityczny” odnosi się do zjawiska wcześniej pozbawionego politycznego charakteru, które wtórnie zostaje upolitycznione ${ }^{14}$. Odnosi się do zjawiska, które Andrzej Czajowski nazywa quasi-politycznym ${ }^{15}$.

\section{Kościół korygujący, oczyszczający rozum polityczny}

Według papieża polityka i wiara pozostają w wewnętrznej relacji. Wiara dla rozumu politycznego jest „siłą oczyszczającą”. Benedykt XVI stwierdza:

Wychodząc od Bożej perspektywy, uwalnia go od zaślepienia, a tym samym pomaga mu być sobą. Wiara pozwala rozumowi [politycznemu - JW] lepiej spełniać jego zadanie i lepiej widzieć to, co jest mu właściwsze. W tym miejscu należy umieścić katolicką naukę społeczną [...]. Chce mieć [ona - JW] udział w oczyszczaniu rozumu i nieść pomoc, aby to, co sprawiedliwe mogło tu i teraz być rozpoznane, a następnie realizowane. [...] Chce służyć formowaniu sumienia w polityce i wpływać na to, aby rosła czujność na prawdziwe wymagania sprawiedliwości i równocześnie gotowość do reakcji w oparciu o nie, również gdy sprzeciwiałoby się to osobistej korzyści. [...] Kościół ma obowiązek współdziałać przez oczyszczanie rozumu i formację etyczną, aby wymagania sprawiedliwości stały się zrozumiałe i politycznie wykonalne. [...] Nie może i nie powinien [...] pozostawać na marginesie w walce o sprawiedliwość. Musi włączyć się w nią przez argumentację rozumową i obudzić siły duchowe, bez których sprawiedliwość, domagająca się zawsze wyrzeczeń, nie może utrwalić się i rozwijać. [...] Kościół jest głęboko zainteresowany budowaniem sprawiedliwości przez otwieranie inteligencji i woli na wymagania dobra ${ }^{16}$.

12 Zob. Benedykt XVI, Przemówienie na spotkaniu z przedstawicielami społeczeństwa brytyjskiego, korpusu dyplomatycznego, świata polityki, nauki i przedsiębiorczości, http://www.opoka.org.pl/biblioteka/W/ WP/benedykt_xvi/przemowienia/gb-westminsterhall_17092010.htlm (dostęp: 1 maja 2016).

13 Zob. Benedykt XVI, Przemówienie w Bundestagu...

14 Zob. ibidem, s. 84.

15 Zob. A. Czajowski, Polityczność działań społecznych, [w:] Polityka i polityczność. Problemy teoretyczne i metodologiczne, red. A. Czajowski, L. Sobkowiak, Wrocław 2012, s. 71.

16 Benedykt XVI, Encyklika Deus Caritas est, nr 28. 
Rolę religii w debacie publicznej Benedykt XVI doprecyzowuje w przemówieniu w Londynie. Rolą religii, a tym samym Kościoła, jest pomoc rozumowi politycznemu (polityków), po pierwsze, w uznawaniu uniwersalnych wartości moralnych, po drugie, w uniknięciu wypaczenia polegającego bądź na daniu się zmanipulować przez ideologię, bądź na takim wybiórczym używaniu rozumu, które nie pozwala w pełni uwzględniać godności osoby ludzkiej ${ }^{17}$.

Benedykt XVI doprecyzowuje również metodę korygowania rozumu politycznego. Akceptacja prawdy dotyczącej uniwersalnych wartości moralnych nie dokonuje się przy użyciu siły,

lecz dzięki perswazji, dzięki heroicznemu świadectwu ludzi o niewzruszonych zasadach i dzięki szczeremu dialogowi, który nie służy obronie własnych interesów, ale ma na celu wspólne dobro ${ }^{18}$.

Perswazja, świadectwo i dialog to metody stosowane przez tych, którzy poszukują prawdy, dobra i piękna. Stosowanie tych metod zbliża ludzi „we wspólnym dążeniu do sprawiedliwości, wolności i pokoju"19.

\section{Benedykt XVI a poziomy konfliktu aksjologicznego w polityce}

Benedykt XVI nie dostrzega, aby Kościół (religia) wykraczał poza swoje kompetencje i zadania, gdy bezpośrednio zajmuje stanowisko aksjologiczne w obszarach zidentyfikowanych na początku artykułu jako poziomy konfliktu aksjologicznego w polityce, a mianowicie w sporach dotyczących wartości fundamentalnych oraz wzajemnych relacji między religią i polityką. Zdaniem papieża takie zaangażowanie Kościoła (religii) nie generuje konfliktu, a w przypadku już istniejącego - łagodzi go. Jest tak w przypadku uniwersalnych obiektywnych wartości ześrodkowanych na wartości pokoju. Nie są możliwe stosunki pokojowe bez stosunków sprawiedliwych, a te z kolei bez odwołania się do prawdy, dobra i wolności. Kościół (religia) może we współczesnym świecie pełnić pozytywną rolę polegającą na korygowaniu rozumu politycznego, czyli nakierowywaniu go na wyżej wymienione wartości. Niewłaściwe ze strony Kościoła (religii) byłoby angażowanie się bezpośrednie w proces polityczny. Podobnie pozytywną i korygującą rolę może pełnić Kościół (religia) w przypadku przypominania personalistycznej antropologii ześrodkowanej na godności człowieka, a tym samym łagodzenia konfliktu generowanego przez niektóre ideologie polityczne.

\section{Podsumowanie}

W artykule prezentuję współczesne podejście nauczania społecznego Kościoła w okresie pontyfikatu Benedykta XVI do problematyki społecznej. Istotną kwestią społeczną na początku XXI w. jest kryzys uniwersalnych wartości, w tym przede wszystkim moral-

\footnotetext{
17 Benedykt XVI, Przemówienie na spotkaniu z przedstawicielami społeczeństwa brytyjskiego...

18 Benedykt XVI, Przemówienie do władz politycznych i administracyjnych Republiki Czeskiej...

19 Ibidem.
} 
nych. Wyraża się on w oddzieleniu życia społecznego, publicznego, politycznego i stanowionego prawa od uniwersalnych wartości. Zaproponowany przez Kościół sposób przezwyciężenia tego kryzysu polega na niepolitycznym działaniu Kościoła oraz przedstawicieli innych religii i ludzi dobrej woli poprzez promowanie uniwersalnych wartości. Promocja wartości jest także zadaniem polityków i prowadzi do politycznych decyzji objęcia wartości ochroną prawną. Z powodu naturalnej słabości rozumu politycznego, według Benedykta XVI, Kościół podejmuje działania korygujące - poprzez perswazję, świadectwo i dialog. Mają one skierować rozum polityczny na wartości i udzielać mu siły do wytrwania przy uznanych uniwersalnych wartościach. Taka aktywność Kościoła (religii) przyczynia się do zmniejszenia aksjologicznego konfliktu w polityce. Artykuł przybliża myśl przywódcy religijnego, jakim jest papież Benedykt XVI, na temat roli religii w konflikcie w obszarze polityki oraz spojrzenie $\mathrm{z}$ perspektywy religijnej na to, jaki powinien być Kościół współcześnie i jak powinien się odnosić do istniejących konfliktów. Zaprezentowane stanowisko jest normatywne, ukazuje, jaki dyskurs i jakie działania powinny charakteryzować przedstawicieli Kościoła, aby nie był on przyczyną konfliktu i aby łagodził powstały już konflikt. Niewątpliwie dla Kościoła jest to punkt odniesienia, drogowskaz na najbliższe lata. Ocena interioryzacji doktryny Benedykta XVI i jej implementacji w praktycznej działalności Kościoła oraz ocena jej wpływu na realny proces polityczny wymaga odwołania się do badań z zakresu socjologii religii i różnych subdyscyplin nauk o polityce, w tym przede wszystkim do nowo tworzącej się subdyscypliny „politologia religii”, które wykraczają poza analizę niniejszego artykułu.

\section{Bibliografia}

Benedykt XVI, Adhortacja Sacramentum Caritatis, Wydawnictwo M, Kraków 2007.

Benedykt XVI, Adhortacja Verbum Domini, Wydawnictwo M, Kraków 2010.

Benedykt XVI, Encyklika Deus Caritas est, WAW KAI, Warszawa 2006.

Benedykt XVI, Przemówienie do władz politycznych i administracyjnych Republiki Czeskiej oraz korpusu dyplomatycznego. 26 września 2009 - Praga, http://www.opoka.org.pl/biblioteka/W/WP/benedykt_xvi/ przemówienia/czechy2009_władze_26092009.htlm (dostęp: 1 maja 2016).

Benedykt XVI, Przemówienie na spotkaniu z przedstawicielami społeczeństwa brytyjskiego, korpusu dyplomatycznego, świata polityki, nauki i przedsiębiorczości, http://www.opoka.org.pl/biblioteka/W/WP/benedykt_xvi/przemowienia/gb-westminsterhall_17092010.htlm (dostęp: 1 maja 2016).

Benedykt XVI, Przemówienie w Bundestagu. 22 września 2011-Berlin, http://www.opoka.org.pl/biblioteka/W/WP/benedykt_xvi/przemowienia/niemcy2011_bundestag_22092011.htlm (dostęp: 1 maja 2016).

Czajowski A., Polityczność działań społecznych, [w:] Polityka i polityczność. Problemy teoretyczne i metodologiczne, red. A. Czajowski, L. Sobkowiak, Wrocławskie Wydawnictwo Naukowe Atla 2,Wrocław 2012.

Dylus A., Polityka w perspektywie etycznej i religijnej, Wydawnictwo UKSW, Warszawa 2016.

Karwat M., O statusie pojęcia 'polityczności', „Studia Politologiczne” 37, 2015.

Karwat M., Polityczność i upolitycznienie. Metodologiczne ramy analizy, „Studia Politologiczne” 17, 2010.

Karwat M., Polityka rzeczowa, stronnicza i metapolityka, „Studia Politologiczne” 8, 2004.

Karwat M., Syndromatyczny charakter przedmiotu nauki o polityce, [w:] Demokratyczna Polska w globalizujacym się świecie, red. K.A. Wojtaszczyk, A. Mirska, Wydawnictwa Akademickie i Profesjonalne, Warszawa 2009. 
Kongregacja Nauki Wiary, Nota doktrynalna o niektórych aspektach działalności i postępowania katolików w życiu politycznym, http://www.opoka.org.pl/biblioteka/W/WR/kongregacje/kdwiary/nota_polityka_24112002.html (dostęp: 1 czerwca 2017).

MacIntyre A., Trzy antagonistyczne wersje dociekań moralnych. Etyka, genealogia i tradycja, przeł. M. Filipczuk, Wydawnictwa Akademickie i Profesjonalne, Warszawa 2009.

Mazurkiewicz, Niepolityczna polityczność Kościoła, „Chrześcijaństwo - Świat - Polityka. Zeszyty Społecznej Myśli Kościoła” 2012, nr 13 (1).

\section{Axiological dispute and its implications for political conflict according to pope Benedict XVI}

Keywords: axiology, Benedict XVI, conflict, politics, religion

Summary

The article provides an analysis of the issue of contemporary axiological disputes related to politics. The article focuses on the approach of pope Benedict XVI to the relation between the Church and politics. According to Benedict XVI the Church should be the promotor of universal values. Its activity in genesis is non-political, but in effects it has political dimensions and the Church should correct public reason of citizens and politicians to accept universal values. If the Church fulfils these requirements, it will contribute to reducing of axiological political conflict in the contemporary world. 